appearance of the self to the self which overcomes the condition of an estranged self"' (p. 126).

Reynolds suggests that he can arrive and has arrived at a fundamental agreement with the "Pinar text's vision or projected world." Despite a number of crucial distinctions, he says, "I can find some sense of a collective voice that I can join" (p. 213). But Ricoeur wrote that he was "most critical" of this communionlike understanding of interpretation. As the "principal flaw" of ontologized hermeneutics, there is an "insistence on understanding as accord, as if the consensus which preceded us was something constitutive" (1981, p. 86).

My criticism of Reynolds' text is not intended to condemn its utopian and ideological character. Rather, I hope I may have suggested ways to make it more of what it seeks to be - a way of dwelling more radically in the critique of his own insuperable ideology. When writing about the broader context of communicative competence, Ricoeur proclaimed that if we do not understand "the dialogue that we are, then we cannot make sense of the dialogue that we ought to be" $(1986, p$. 250).

\title{
References
}

Gadamer, H. (1981). Truth and method (F. Lawrence. Trans.). Cambridge, MA: MIT Press.

Gadamer, H. (1981). Reason in the age of science (F. Lawrence, Trans.). Cambridge, MA: MIT Press.

Ricoeur, P. (1973, Summer). Ethics and culture: Habermas and Gadamer in dialogue. Philosophy Today, XVII(2/4), 152-165.

Ricoeur, P. (1976). Interpretive theory: Discourse and the surplus of meaning. Fort Worth: Texas Christian University Press.

Ricoeur, P. (1977). The model of the text: Meaningful action considered as text. In F. Dallymar \& T. McArthy (Eds.), Understanding and social inquiry (pp. 316-334). Notre Dame: University of Notre Dame Press.

Ricoeur, P. (1981). Hermeneutics and the human sciences: Essays on language, action and interpretation (J.B. Thompson, Ed. and Trans.). Cambridge: Cambridge University Press.

Ricoeur, P. (1986). Lectures on ideology and Utopia (G.H. Taylor, Ed.). New York: Columbia University Press.

Thompson, J.B. (1981). Critical hermeneutics: A study in the thought of Paul Ricoeur and Jurgen Habermas. Cambridge: Cambridge University Press.

Stephen Bath

The Insurance Corporation of British Columbia

\section{Maternal Thinking. Toward a Politics of Peace by Sara Ruddick. Boston:} Beacon Press, 1989.

The story I have told is not the only one about mothers or about peace. Many politics are needed, many wills, many moral and intellectual inventions. A feminist maternal peace politics is one story. It makes a beginning that, like birth itself, reviews hopes as old and at least as indestructible as war. (p. 251)

Ruddick's final statement summarizes much of what I like about Maternal Thinking. Her "story" is touched by a humility that can only come through a deep confidence that its message holds truth. The stories of women as mothersher own stories and those of others, fictional and nonfictional-are skillfully woven throughout. To introduce a concept, to clarify a point, to deepen an 
understanding, to engage our feelings Ruddick's mothers stand side by side with her philosophers; the concrete with the abstract; Virginia Woolf with Wittgenstein.

The story begins with Ruddick's own. We meet a young woman whose "life has been shaped by a love affair with Reason" (p. 3). Bright, ambitious, Ruddick learns early that to be a successful player in the world she would need (and want) to "free herself from the fate of wife-and-mother with its messy, fleshy children and dull duties" (p. 5) and move over to the "right side of power" (p. 6), the place of the Fathers and Reason. Love of Reason led eventually to betrayal, rebellion, and questions. Ruddick began to ask whether there might always be ways of conceptualizing reason that derive from women's work and experiences. The answers she found, the thinking she did, the experiences she had led her to claim that "maternal thinking" exists; that it is a distinctive way of knowing arising out of the practice of mothering.

In Part I, "Thinking About Mothers Thinking," Ruddick lays the philosophical foundation for her claim. Here the epistomological connection is made between thought and practice in general. A "practice" is a "collective human activity" (p. 13) distinguished by its own aims or goals and criteria of truth. Practitioners of a distinct practice share in its ways of knowing, its values, its beliefs, and are able to test their practice against certain agreed criteria. Thinking arises from the practice as individuals make sense of their activities.

For example, when I engage in the practice of teaching, I share with other like-minded educators a common language, body of knowledge, beliefs, and values. When I reflect on my experience, meaning arises for me as I compare or judge the evidence I have perceived against the standards and criteria shared with educators. It is within the practice, therefore, that its truth is located. As I consider this statement, the importance of reflective practice clearly emerges; for if educational thinking, like "psychoanalytic, critical, or historical thinking, depends on the community of participants in which it arises and their truths are tested by shared criteria" (p. 15), then it becomes the responsibility of the participants within the community to experience, to reflect, to share, to test, and to move forward the practice. This is what Sara Ruddick has done.

Maternal work, Ruddick argues, is also a practice as distinct as any other, "whether the practice be religious, scientific, [or] critical" (p. 16). Its goals emerge out of the "demands" imposed on the mother by the child and the social world in which she works. Ruddick distinguishes three primary demands that constitute maternal practice: the demands for preservation, for growth, and for social acceptability. She acknowledges that demands is an artificial term and that this schema "belies the jumbled unity of mothers' lives" (p. 61). Nevertheless, she points out, "a reflective mother can separately identify each demand, partly because they are often in conflict" (p. 23). It is most often because of these daily conflicts and the need for action that mothers must think. Conflicts provoke thinking and reflection. Conflicts bring mothers together in search of specific strategies, attitudes, and virtues that will help forward their commitment to protect, nurture, and train their children.

In Part II, "Protection, Nurturance, and Training," Ruddick moves out of the realm of background and into the specifics of maternal work. Here she dons the hats of inventor, reader, observer, and mother. Here we meet reality: the women 
who shared their stories; the mothers who passionately relate their pain and confusion, their triumphs and failures. Through anecdote and description, Ruddick identifies "some of the specific metaphysical attitudes, cognitive capacities, and conceptions of virtue that arise from mothering" (p. 61).

We are first introduced to preservation love and Julie:

I stumble towards your room and switch on the low lamp so the light will not startle you. You toss your body back and forth, arch your back and wail and call. Trembling, I walk to your bed and check your diaper. I try to speak, to soothe, to give voice to my presence, but my throat constricts in silent screaming and I find I cannot touch your tangled blankets. I force myself to turn and walk away, leaning against the door jamb. My knees buckle beneath me and I find myself huddled on the floor. "Please do not cry. Oh child I love, please do not cry. Tonight you can breathe, so let me breathe." And I realize my chest is locked and I am gasping for breath. I picture myself walking towards you, lifting your tininess in both my hands and flinging you at the window. Mixed with my choking I can almost hear the glass as it would smash and I see your body, your perfect body, swirl through the air and land three stories below on the pavement. (p. 67)

What can we learn about protective thinking from Julie's story? Witness the following statement:

mothering makes reflective feeling one of the most difficult attainments of reason. In protective work, feeling, thinking, and action are conceptually linked; feelings demand reflection, which is in turn tested by action, which is in turn tested by the feelings it provokes. (p. 70)

In addition to reflective feeling, Ruddick identifies other cognitive capacities and virtues of preservative thinking: the "scrutinizing gaze" as "the watchful eye of preservative love" (p. 72); humility, the "selfless respect for reality ... a way of persevering and controlling in an exhausting, uncontrollable world" (p. 73); clear-sighted cheerfulness and resilience; an appreciative, respectful sense of nature; a "holding" attitude, holding together, harmonizing. Nowhere does Ruddick sentimentalize mothering or claim that all mothers exhibit all aspects of preservative thinking. Rather, she notes that each is liable to lapse into degenerative forms and that, at its best, mothering is a struggle toward the ideal.

In like manner, Ruddick looks at how the demand to foster growth structures maternal thinking. Fostering growth requires "a welcome response to change" (p. 89) in which "a mother makes herself into a trustworthy listener" (p. 93) in order to understand the child's mind. In learning to listen, in accepting and working with change, mothers tend to adopt a more concrete style of thinking. Although she does not deny women's ability to think abstractly and, in fact, notes its usefulness in maternal work, Ruddick claims that it is the more concrete style of cognition, common to maternal thinking, that values and accepts connectedness, complexity, ambiguity, and open-mindedness.

Like abstract cognitions, the reflectiveness of concreteness must be developed. Here Ruddick speaks of the beauty and power of story. For mothers, maternal stories develop their attentiveness, their reflectiveness. They build self-confidence and understanding of their own and their children's lives. They provide a means of sharing their knowledge. They establish a collectivity of mothers and 
connect mother with child. For children, maternal stories reassure and remind; help them to accept and understand; and ultimately, Ruddick states, "enables children to adapt, edit, and invent life stories of their own" (p. 98).

It is in the final chapter in Part II, "Training: A Work of Conscience?" that Ruddick, speaking as a mother, speaks the most harshly of her kind. She identifies two struggles within maternal practice: between inauthenticity and conscience and between domination and educative control.

For most mothers, training their children is confusing and fraught with selfdoubt. Under pressures to produce "acceptable" children, mothers are often left on their own with few or rapidly changing guides. Conflicts and dilemmas surface and often a mother must reflect back on her own moral principles. Inauthenticity and domination will arise when there is a discrepancy between the private and public mother; when "the powerful, confident mother [is] rendered confused and powerless by the gaze of others" (p. 111). In denying her own authority, the inauthentic or dominating mother may find herself at odds with her commitment to protect and nurture her children.

Fortunately, according to Ruddick, mothers often "display a sturdy independence of mind and the courage to stand up for their children even when this means standing against Fathers they love or fear" (p. 116). The necessary virtue to be developed here is one Ruddick calls "proper trust" and requires a mother's clear judgment, reliability, goodwill, and independence. A tall order, "one of the most difficult maternal virtues" (p. 119) the attainment of which, Ruddick suggests, is an ongoing difficult struggle.

In Part III, the final section, Ruddick brings maternal thinking to bear on military thinking and peace politics. She looks critically at mothers' wars and men's wars and the myths and rhetoric associated with both: the mater dolorosa, the macho heroes, the romantic warriors, the technostrategic reasoning of today's warfare. She considers maternal nonviolence, both its dark side and the ideal, aware that although a mother may not be intrinsically peaceful, the work of mothering demands that she "maintains conditions of peacefulness so that her children can grow in safety" (p. 160). Mothers live with conflict, and in their own homes they struggle daily with finding and using nonviolent strategies, in reconciling relationships, in keeping the peace. It is its struggles and the thinking that is provoked that, Ruddick believes, makes maternal practice "a 'natural resource' for peace politics" (p. 157).

Maternal Thinking is a brave book. It carries a vision and uses the language of both fathers and mothers to forward its cause. I found it useful and interesting in many ways: in reflecting on my own experiences as an educator/caretaker, as a woman/daughter/stepmother; in recognizing the power of the story in deepening one's knowledge and understanding; in following a well-crafted, intelligent unfolding of an argument; and in sharing with Ruddick her hopes for peace. As she says so well, Maternal Thinking "makes a beginning that, like birth itself, reviews hopes as old and at least as indestructible as war" (p. 251).

Alannah Ireland 